\title{
Development of the 4E-FTE Engine Simulator Trainer to Improve Learning Outcomes through Problem Based Learning
}

\author{
Tohadi1, a*, Muchlas Samani1,b, I Wayan Susila1,c \\ 1Department of Vocational Education, Surabaya State University, Surabaya, 60213, Indonesia \\ a tohadi@mhs.unesa.ac.id; b muchlassamani@unesa.ac.id; 'c wayansusila@unesa.ac.id \\ *Corresponding Author \\ Whatsapp Number [+6281330519247]
}

\begin{abstract}
How to Cite: Tohadi, T., Samani, M., Susila, I. W. (2020). Development of the 4E-FTE Engine Simulator Trainer to improve learning outcomes through Problem Based
\end{abstract} Learning. International Journal for Educational and Vocational Studies, 2(8), 702-707. DOI: https://doi.org/10.29103/ijevs.v2i8.2692

\section{ARTICLE HISTORY}

Received: 4 July 2020

Revised: 11 July 2020

Accepted: 17 July 2020

\section{KEYWORDS}

Trainer Simulator Engine 4E-FTE; Engine Management System;

Problem Based Learning;

Learning tool Effectivity;

\begin{abstract}
This research aims development of the 4E FTE simulator trainer and peripheral equipment which is integrated with the problem based learning model from validated 4D Models trainer simulators: (1) pedagogical aspects; (2) conceptual aspects and; (3) conceptual aspects. Developed trainer simulator is able to improve cognitive, affective and psychomotor domains of learning outcomes. Questionnaire and student achievement test were used as research instruments. Data analysis was performed to determine the level of validity, practicality and student learning outcomes which include learning outcomes in the cognitive, affective and psychomotor domains. This research found some evidence (1) There was no significant difference in cognitive domain learning outcomes using the 4E FTE engine simulator trainer which was compared to learning outcomes using the engine stand with a mean value of 82.36 and for the engine stand class with a cognitive mean value of 80.55 ; (2) Based on affective domain learning outcomes for students who use the 4E FTE engine simulator trainer perspective, there were significant differences compared to students who learn using the engine stand, with an affective domain mean value of 85.64 , mean engine stand of affective value 84.62, and; (3) There was no significant difference between the Problem Based Learning (PBL) model using the 4E FTE engine trainer simulator with the engine stand on psychomotor student learning outcomes. The mean value of the psychomotor domain was 79.39 while the mean value of the psychomotor was 78.64 .
\end{abstract}

This is an open access article under the CC-BY-SA license.

\section{INTRODUCTION}

The purpose of Vocational Education is to increase intelligence, knowledge, personality, noble character, and skills to live independently and to follow further education in accordance with their vocational training (Yasak \& Alias, 2015). Vocational High School (VHS) at basic vehicle engineering Expertise Program aims to; (1) Improving students' faith and devotion; (2) Educating students to become responsible citizens; (3) Educating students to be able to apply healthy living, have insight into knowledge and art; (4) Educating students with expertise and skills in the Basic vehicle engineeringexpertise program, so that they can work either independently or fill jobs in the business world as mid-level workers; (5) Educating students to be able to choose a career, compete and develop professional attitudes in the Basic vehicle engineeringexpertise program; and (6) Equipping students with knowledge and skills as provisions for those interested in continuing to higher education (Ahmad, 2015).
According to Azhar (2010) it was concluded that learning outcomes achieved $90 \%$ of what was said and done. This shows if the teacher asks students to do something and report it, then they will remember and master as much as 90\%. Many industries have complained that Vocational High School graduates are not ready to use as evidenced by the large number of our students who were not accepted at the time of registration at an official workshop in collaboration with Vocational high school at Surabaya. Following are the data of students who were accepted in the superior class programthat from year to year the number decreased as well as due to the need factor also because of the student's ability factor.

Judging from the value of student in Basic vehicle engineering XII, new sutdent can meet the minimum completeness criteria value, must make improvements up to twice. This is because in the teaching and learning process the unavailability of media trainer simulators that can help bridge the learning process of electrical 
vehicle repair subjects with Basic competencies Maintaining engine management systems. For this reason, the research developed the creation of a $4 \mathrm{E}$ FTE engine trainer media trainer to improve learning outcomes in subjects maintaining the engine management system.

Starting from the description above, one of the efforts that will be taken to improve the quality or learning outcomes of the subject of the engine management system is by developing a trainer engine $4 \mathrm{E}$ FTE simulator and applying a learning model based on problems. This research is relatively new in terms of the application of learning media that gives students the opportunity to try, test, and analyze errors in the EMS system in four-wheeled vehicles. namely the application of media trainers in learning, so it is worth continuing. Whether or not a new study can be seen and compared with the results of previous studies.

Jamaluddin (2014) conducted a study on the development of audio learning media in relation to improving listening skills in english subjects at the high school students, with the conclusion that learning using audio media can improve listening skills in English subjects. Yew and Goh (2016) in his research on the effectiveness of model-based learning aids assisted by teaching aids and problem cards on the ability to solve quadrilateral material in State Junior High School 1 Pringsurat Semarang, concluded that the problem based learning (PBL) model assisted with props and problem cards can improve students' ability to solve problem, so it can be said to be very effective. Sean (2015) in the title of his research concluded that learning the introduction of simple geometric shapes with a demonstration of concrete objects can improve students' understanding and achievement of simple geometric shapes in the School. Zahid et al (2016) in the title of his research concluded that the problem based learning model can increase student learning activities from the cycle of cycles, learning outcomes increase after the application of the problem based learning model. Mubarok (2016) in a study on the Development of Macromedia Flash 8 Learning Media on Conventional Fuel System Competencies to Improve Student Learning Outcomes, concluded that the learning media of conventional fuel systems can be used to improve student learning outcomes at Vocational High School (VHS) Cipta Karya Prembun.

\section{LITERATURE REVIEW}

\subsection{Learning Media}

Everything that can be used to channel messages from the sender to the recipient so that it can stimulate the thoughts, feelings, concerns and interests of students in such a way that the learning process occurs as expressed by Setyawan, F., \& Suprianto, B. (2014) so that with the media will be achieved the purpose of learning. This is very helpful in learning with PBM models. Where problems are presented through learning media will help students to think at a high level with the help of teacher or friend guidance.

\subsection{Trainer simulator Engine 4E-FTE}

Trainer is part of the learning media, where the learning media itself is all the objects that mediate the learning process, both tangible software and hardware. Bhise and Amte (2015) states that the trainer is an application simulation process of building a model of a real system or a proposed system, conducting experiments with the model to explain system behavior, study system performance, or to build a new system in accordance with the desired performance. According to Samanol et al (2014) states that the trainer is a set of equipment in the laboratory that is used as an educational medium which is a combination of work models and mock-ups. The mock-up model is a simplification of the arrangement of the main parts of a more complicated process or system (Helander 2006).

\subsection{Problem Based Learning}

Learning is a process of interaction of students with educators and learning resources in a learning environment. It should be underlined that in learning there are interactions between students and learning resources. Learning resources in this study are learning media and their modules Aryulina, D. \& Riyanto, R. (2016) . The media along with this tutorial module will be the focus of their research. With the learning media and modules, the learning process is easier. According to Gagne (1985) in Personal learning can be interpreted as "a set of events embedded in purposeful activities that facilitate learning." Learning is a series of activities that are intentionally carried out with a view to facilitate the learning process.

Major and Mulvihill (2017) states that Problem based learning is learning that results from the process of working toward the understanding or resolution of a problem. Problem based learning is learning that results from work processes leading to understanding or solving a problem. Furthermore, according to Neo, Ehyn, and Megan (2002) problem-based learning will greatly motivate students both individually and in groups to solve problems as a form of their understanding.

Problem based learning (PBL) has characteristics such as learning begins with giving problems, usually problems have a context with the real world, learners / students in groups actively formulate problems and identify gaps in their knowledge, learn and find their own material related to the problem and report solutions to problems Saleh et al (2018).

\subsection{Learning Outcomes}

In every teaching and learning activities carried out must have an instructional goal that is instructional. Instructional goals are learning goals that can be clearly and operationally known by a teacher and student. The purpose of teaching and learning activities themselves is a change in behavior in a syudent (Kumpas \& Veispak, 
2018) . Changes in student behavior both in terms of knowledge, attitudes and skills in students majoring in basic vehicle engineeringwhich in the basic competence of the EMS. This change in behavior is the expected learning outcome in the learning process. According to Hamalik (2013) that learning outcomes will be seen in every change in aspects of knowledge, understanding, habits, skills, appreciation, emotional, social relations, physical, ethical or manners, and attitudes. If someone has done the act of learning it will be seen a change in one or several aspects of the behavior.

Learning outcomes are the most important part in learning. Sudjana, Nana \& Ibrahim (2012) defines student learning outcomes in essence is a change in behavior as a result of learning in a broader sense covering the cognitive, affective, and psychomotor fields. According to Suprijono (2013) that learning outcomes are changes in behavior as a whole not just one aspect of humanity's potential. According to Jihad and Haris (2012) that learning outcomes are attainments of behavioral change that tend to settle from the cognitive, affective, and psychomotor domains of the learning process carried out within a certain time. Based on the understanding of learning outcomes above, it can be concluded that learning outcomes are the results obtained by students after the students carry out learning and learning activities as well as evidence of success that has been achieved by someone that includes the cognitive, affective and psychomotor domains, which are expressed in symbols, letters and sentence.

\subsection{Student Response}

Roudhonah (2019) said the response is a reaction, meaning acceptance or rejection, as well as an indifferent attitude to what is conveyed by the communicator in his message. Responses can be divided into opinions (opinions) and attitudes, where opinions or opinions are open answers (overt response) to an issue expressed in words spoken or written. While attitude is a closed reaction (convert response) that is emotional and personal, is a tendency to give a very positive or negative reaction to people, objects, or certain situations (Grez, Valcke, \& Berings, 2010).

Researchers concluded that the response is a reaction/ response/opinion arising from the stimulation contained in the surrounding environment. So that student responses are reactions or responses shown by students in the learning process environment to the $4 \mathrm{E}$ FTE engine simulator trainer. One way to find out someone's response to something is to use a questionnaire, because the questionnaire contains questions that must be answered by respondents to find out facts or opinions.

\section{METHODS}

This research is a development research (development research), because it develops a engine $4 \mathrm{E} \mathrm{FTE} \mathrm{simulator}$ trainer along with a tutorial module, LIP (Learning
Implementation Plan), Student Worksheet (SW) and Assessment Sheet (AS). The purpose of the research method is to produce a product and test the practicality of the product (Sugiyono, 2013).

The definition phase (define) includes five phases: (a) initial-end analysis (front-end analysis); (b) learner analysis; (c) task analysis; (d) concept analysis; and (e) specific instructional objectives (specifying instructional objectives). The design phase includes four phases: (a) constructing a constructing criterion- test; (b) media selection, (c) format selection; and (d) initial design. The development phase includes two phases: (a) expert appraisal; and (b) referenced developmental testing. The dissemination phase includes three phases: (a) validating testing; (b) packaging; and (c) diffusion and adoption.

The trial design used in this study was Pretest-Posttest Control Group Design (Sugiyono, 2013), in which the Experiment (O1) and Control (O3) groups received initial tests (pre-tests.) Then both groups were treated learning with the 4E FTE engine simulator trainer in Class XII of Basic vehicle engineering1 namely (X1) for the experimental group and for Class XII of Basic vehicle engineering3 were treated with the learning engine stand (X2) for the control group. Furthermore, after the treatment a post-test was held, for both groups $\mathrm{O} 2$ (experimental class) and $\mathrm{O} 4$ (control class).

In this research design, taking subjects was not done randomly. This design was chosen because during the experiment it was not possible to change the existing class pre test used to equalize the initial knowledge of the two groups while the post test was used to measure student learning outcomes after being treated. In the control class the implementation of learning uses only the engine stand. Then the pre-test and post-test, the implementation of learning guided by the LIP. The trial was conducted on students of class XII Basic vehicle engineering3 on maintaining the EMS system material. Data obtained from the control class is used to analyze and revise the learning process that will be implemented in class XII of Light Vehicle Engineering

Implementation of learning in the experimental class using the $4 \mathrm{E}$ FTE engine trainer media simulator. Then do the pre-test and post-test. Learning is guided by the RPP which aims to find out the improvement in student learning outcomes after using a trainer on basic competencies maintaining the EMS system. The trial was conducted on students of class XII Basic vehicle engineering1. Data obtained from the experimental class is used to analyze and revise the learning process that will be implemented in class XII Light Vehicle Engineering.

\section{RESULTS AND DISCUSSIONS}

\subsection{Description and Analysis of the Trainer Simulator Devices}

Based on the results of the validation data analysis and trainer simulator testing, it is known that the $4 \mathrm{E} \mathrm{FTE}$ engine simulator trainer can work well. This is very 
clearly seen from the results of the validation of experts with an average value of $86 \%$, thus the $4 \mathrm{E}$ FTE engine simulator trainer is included in the category of very feasible to use. While the results of the practical validation of the trainer simulator with an average value of $86 \%$, the trainer simulator is included in the very feasible category and can be used.

The results of the validation of the device in general provide criteria with $87 \%$ syllabus instruments, $85 \% \mathrm{RPP}$ instruments, $89 \%$ LKS instruments, and $87 \%$ tutorial module instruments, so that learning tools are suitable for use in data collection through the learning process. The results of observations of the implementation of learning were analyzed using quantitative descriptive analysis obtained an average value of $87.59 \%$, the implementation of learning can be concluded that learning is carried out to completion and systematically in accordance with the RPP. As for student responses, the average value was $85 \%$, so students gave very positive responses to the $4 \mathrm{E}$ FTE media trainer simulator on learning EMS material.

Based on the trainer simulator test results that of the 15 items EMS components on a vehicle can work normally as expected starting from the battery voltage, Electric Control Unit (ECU), Igniter, Trottle Position Sensor (TPS), In Take Air Temperature (IAT), Water Temperature Sensor (WTS), Mass Air Pressure (MAP), Distributors, Circuit Opening Relays, Ground, Oxygen Sensors (O2), Ignition Switch ST, Injectors 1 \& 3, and Injectors $2 \& 4$. Thus technically a $4 \mathrm{E}$ FTE engine simulator trainer can work well and normal.

\subsection{Cognitive Learning Outcomes}

The results showed a summary of statistical results from the experimental class and the control class for the post test scores of the experimental class obtained an average value of 82.36 , while for the value of the Control class obtained an average value of learning outcomes of 80.55. The number of respondents was 36 students. For Std. The posttest test deviation of the experimental class was 8,903 , while the control class was 7,817 and the Std Error Mean for the pretest for the experimental class was 1,483 and the control class was 1,302 , the score of the experimental class was higher than the control class. Based on the results of the $\mathrm{T}$ Test, the value of $\mathrm{t}=0.914$ is obtained and the value of Sig. (2-tailed) for the experimental and control class of $0.364>0.05$, because the value of sig. (2-tailed) of 0.364 is greater than 0.05 , it can be concluded that there is no difference in cognitive domain learning outcomes, meaning that between the experimental class and the control class have the same knowledge competence.

Learning outcomes of the cognitive domain of the experimental class have higher average values due to: First, there is a relationship between learning characteristics with students. In learning with the learning model based on the problem that is the center of learning is students, students are required to find existing problems and then identify problems. Secondly, there is a match between the E FTE engine simulator media trainer in the experimental class with the characteristics of the learning material. With this media, experimental class students in learning to find problems by observing, collecting data, and group discussions. They become quite active in asking questions, discussing the characteristics of components as a source of problems based on Student worksheet with a group of friends and answering questions about the training that is in Student worksheet. Third, experimental class students are taught to explain an existing concept or problem, and can find new concepts according to existing data and establish concepts with existing theories.

\subsection{Affective Domain Learning Outcomes}

The results showed the mean affective domain of the experimental class was 85.64 higher than the mean of the affective domain of the control class obtained with a value of 84.62, so in this study it was concluded that there was an influence on the use of the 4E FTE engine simulator trainer applied to improve the realm of learning outcomes Affective learners significantly. Likewise, the results of the $\mathrm{t}$ test show that the Sig. (2-tailed) of $0.019<0.05$, because of the sig. (2-tailed) of 0.019 is smaller than 0.05 , it can be concluded that there are differences in affective domain learning outcomes, meaning that between the experimental class and the control class have significant differences.

\subsection{Psychomotor Learning Outcomes}

Psychomotor domain of learning outcomes $\mathrm{t}$ value $=0.873$ and Sig. (2-tailed) for the experimental and control class of $0.386<0.05$, because the value of sig. ( 2 -tailed) of 0.386 is greater than 0.05 , it can be concluded that there are no differences in learning outcomes in the psychomotor domain, meaning that between the experimental class and the control class have the same skill competencies.

The cognitive learning outcomes of the experimental class have a higher average value due to the existence of a match between the $4 \mathrm{E}$ FTE engine simulator media trainer in the experimental class with the characteristics of the learning material. So students are able to improve learning outcomes in the psychomotor domain if compared to the control class. However, the lack of media where one media is used for one class practicum alternately causes less than optimal results. Where is the ideal every 4 Students use 1 learning media.

\subsection{Discussion}

The results found that the learning outcomes of the affective domain of students who used the 4E FTE engine trainer simulator were significantly higher than students who used the engine stand. The results of this study are in line with the research of Lee and Osman (2012) concluding that learning outcomes with modules show significant differences between the control group and the experimental group in understanding concepts and characters in electrochemical learning. This is in line with 
the results of Suprianto research (2015) which concluded that the completeness of students' affective learning outcomes was $83.88 \%$. This is supported by data that students can form in the character of honesty, responsibility, discipline, cooperation, and curiosity.

The results found that there were no differences in psychomotor learning outcomes between students who used the $4 \mathrm{E}$ FTE engine trainer simulator compared to students who used the engine stand. This is not in line with the results of research by Gammie's research (2012) which concluded that the media and modules can improve the results of the ability of students' performance skills well. The limitations of the research sample should be more than 2 schools, while this research uses a sample of only one school due to the limitations of the trainer simulator tool. This study is also not in line with the results of Maidou and Polatoglou (2014), the conclusion that students are more skilled in the use of laboratory equipment because of the lack of media where one media is used for practicing one class in turn this causes less than optimal results. Where is the ideal every 4 students use 1 learning media.

\section{CONCLUSION}

The use of the $4 \mathrm{E}-\mathrm{FTE}$ engine simulator trainer that is guided and observed by the teacher during the learning process with a problem based learning model to improve learning outcomes in the cognitive, affective, psychomotor domains compared to students taught using the engine stand on EMS competencies.

To apply the learning model based on media-assisted problems, students need to be given more adequate preparation especially in terms of mastery in learning to describe the design and implement the associated 4E-FTE engine simulator trainer. With sufficient preparation, during the implementation of learning it is expected that there will not be many obstacles in planning and operating aspects, that the use of the problem based learning model taught in the 4E-FTE engine simulator trainer class is better than the class taught in the engine stand class, it is : (1) student learning outcomes both higher cognitive learning outcomes, and psychomotor domains all of the 4E-FTE engine simulator trainer classes there was an increase from the engine stand class but there were no significant changes; and (2) the problem based learning model will be better because students are required to be independent in completing each task.

\section{REFERENCES}

Ahmad, H. (2015). Leadership in TVET for the 21st Century: Challenges, Roles and Characteristics. Procedia-Social and Behavioral Sciences, 19(5), 1471-1476. doi:10.1016/j.sbspro.2015.06.446

Aryulina, D. \& Riyanto, R. (2016). A problem based learning model in biology education courses to develop inquiry teaching competency of preservice teachers. Cakrawala Pendidikan, 1(1), 47-57. doi:10.21831/cp.v1i1.8364.

Azhar, A. (2010). Media Pembelajaran. Jakarta: PT. Raja GrafindoPersada.

Bhise, K., \& Amte, S. (2015). Embedded PLC Trainer Kit with Industry Application. International Journal of Engineering Science and Innovative Technology.4(3), 58-65

Gagne, Robert. M. (1985). The Conditioning of Learning and Theory of Instruction. $4^{\prime \wedge}$ ed New York :Holt, Rinehart \& Winston. P. 125

Gammie (2012) Operating a distance learning module within an undergraduate work placement. Journal of Technology and Science Education, 9(3), 282-294. doi:10.3926/JOTSE.631.

Grez, D., Valcke, \& Berings. (2010). Student response system and learning oral presentation skills. Procedia-Social and Behavioral Sciences, 2(2), 1786-1789. doi:10.1016/j.sbspro.2010.03.985

Hamalik, O. (2013). Proses belajar mengajar. Jakarta: Bumi Aksara.

Helander, M. G. \& Khalid, H. M. (2006). Affective and Pleasurable Design, In: Salvendy, G. (ed.), Handbook of Human Factors and Ergonomics. New York: Wiley Interscience.

Jamaluddin, H., et.al. (2014). Development of Training Kit for Learning Taguchi Method and Design of Experiments. Jurnal Teknologi (Sciences \& Engineering). 68(4),19-25.

Jihad A. \& Abdul H. (2012). Evaluasi Pembelajaran. Yogyakarta: Multi Presindo.

Kumpas-Lenk, K., Eisenschmidt, E., \& Veispak, A. (2018). Does the design of learning outcomes matter from students' perspective?. Studies in Educational Evaluation, 59, 179-186.

doi:10.1016/j.stueduc.2018.07.008

Lee dan Osman (2012) Interactive multimedia module in the learning of electrochemistry Interdisciplinary. Journal of Problem-Based Learning, 12(2), 1-13. doi:10.7771/1541-5015.1746.

Maidou dan Polatoglou (2014), Motivating weak secondary vocational school students through participating with scientific projects in a students' conference. Journal of Experimental Education, 84(4), 764-786. doi:10.1080/0 0220973.2015.1083521.

Major, T. \& Mulvihill, T. M. (2017). Problem-based learning pedagogies in teacher education: The case of Botswana. Interdisciplinary Journal of Problem-Based Learning, 12(1), 1-11. doi:10.7771/1541-5015.1543.

Mubarok, K. (2016). Development of Macromedia Flash 8 Learning Media on Conventional Fuel System competencies to Improve Student Learning Outcomes in Class XI TKR in SMK Cipta Karya Prembun Academic Year 2014-2015. Jurnal Teknologi (Sciences \& Engineering). 68(4),19-25.. 
Neo, K. W., Ehyn, Y. K., \& Megan. (2002). Authentic problem based learning. Singapore: Prentice Hall.

Roudhonah. (2019). Ilmu Komunikasi. PT Rajagrafindo Persada: Depok.

Samanol, S.B., Hamid, S.B.A., \& Ramli, M.N.B. (2014). Development of Pneumatic Trainer Kit For Polytechnic Student. Journal of Mechanical Manufacturing (J-Mfac). 1(14), 178-183

Saleh, A., Silver, C. H., Chen, Y., Shanahan, K., Rowe, J., \& Lester, J. (2018). Scaffolding peer facilitation in computer-supported problem-based learning environments. In J. Kay \& R. Luckin (Eds.). Rethinking learning in the digital age: Making the learning sciences count, 13th International Conference of the Learning Sciences (ICLS) 2018, Volume 3. London, UK: International Society of the Learning Sciences, pp. 1831-1834. doi:10.22318/ $\operatorname{cscl} 2018.1831$.

Sean, C. (2015). BeRobot-The Robotic Scientific Education Development Kits. Lovotics, an open access journal. 3 (1),1-4.

Setyawan, F., \& Suprianto, B. (2014). Pengembangan Trainer dan Job-Sheet PLC Sebagai Media Pembelajaran pada Mata Diklat PLC di Jurusan Elektronika Industri SMK Negeri 2 Lamongan. Jurnal Pendidikan Teknik Elektro. 3(3), 509-515.

Sudjana, Nana \& Ibrahim. (2012). Penelitian dan Penilaian Pendidikan. Bandung: Sinar Baru Algensindo.

Sugiyono. (2012). Metode penilitian kuantitatif, kualitatif dan $R \& D$ cetakan ke 17. Bandung: Alfabeta.

Suprijono (2013). Cooperative Learning Teori dan Aplikasi PAIKEM. Yogyakarta: Pusaka Pelajar.

Suprianto (2015) Pengembangan Media Trainer dan Modul Mikrokontroler Atmega 8535 Aplikasi Sensor Warna TCS230 dan Sensor Gas MQ6 Sebagai Media Pembelajaran pada Mata Diklat Mikrokontroler di SMKN 2 Bojonegoro. Jurnal Pendidikan Teknik Elektro, 1(2), 509-515.

Yasak, Z., \& Alias, M. (2015). ICT Integrations in TVET: Is it up to Expectations?. Procedia-Social and Behavioral Sciences, 204, 88-97. doi:10.1016/j.sbspro.2015.08.120

Yew, E. H. J., \& Goh, K. (2016). Problem-based learning: An overview of its process and impact on learning. Health Professions Education, 2(2), 75-79. doi:10.1016/j. hpe.2016.01.004..

Zahid, M. A., Varghese, R., Mohammed, A. M., \& Ayed, A. K. (2016). Comparison of the problem based learning-driven with the traditional didactic-lecturebased curricula. International Journal of Medical Education, 1(7), 181-187. doi:10.5116/ijme.5749.80f5 